\title{
"So, it is about how negative it is?!" \\ Understanding researcher/researched interactions as relations between intersectional social positions
}

\author{
Sune Qvotrup Jensen
}

\begin{abstract}
The article argues that interactions in qualitative interviews and ethnography can be analyzed as relations between intersectional social positions. It draws attention to the importance of class and geographical location in such analysis. It further argues that such interactions work through typifications, that they have a power dimension and that they entail processes of identity formation. The identities being offered through these processes can, however, be negotiated or resisted. The article then analyses such interactions as they were experienced in two research projects the author participated in: His PhD project about young marginalized ethnic minority men, and the collective project INTERLOC which focused on the interplay between gender, class, ethnicity and 'race' in an underprivileged Danish suburb. It is demonstrated that relationality influences the assumptions research participants have about the researcher. It is also demonstrated that the research encounter entails powerful mechanism of identity formation. The informants, however, sometimes resist these processes resulting in blurred and unstable, sometimes antagonistic, power relations. It is finally argued that analyses of such interactions can provide central insight into the subject studied.
\end{abstract}

Keywords: ethnography, intersectionality, typification, location, class, gender, ethnicity, 'race', difference, qualitative methods

Please cite this article as: Qvotrup Jensen, S. (2012). "So, it is about how negative it is?!" Understanding researcher/researched interactions as relations between intersectional social positions. Qualitative Studies. 3(2): 115-132.

\section{Introduction:}

This article analyses the methodical experiences from two research projects: My PhD Project which focused on forms of masculinity among marginalized ethnic minority men in Denmark, and the collective project INTERLOC ${ }^{1}$ which focused on intersectionality and local citizenship in an underprivileged Danish suburb.

Although these two research projects had different aims, they had in common that I, as a researcher, interviewed, or did ethnography among, people who were positioned differently from me in terms of class, ethnicity, 'race', age, position and geographical location. There were also similarities in the way the researcher-researched interactions turned out. The people I interviewed sometimes had quite specific ideas about my intentions, perspectives and ideas about them - even in situations where I had not yet informed them about the purpose of the research. They were also in some cases rather cautious, and occasionally the interactions were somewhat antagonistic.

The aim of the article is to undertake a sociological analysis of the mechanisms structuring or conditioning such interactions between researcher and researched. The analysis draws inspiration from Bourdieu's sociology, poststructuralist theory, as well as Järvinen \& Mik-

${ }^{1}$ Intersectionality and local citizenship, see www.interloc.aau.dk 
Meyer's (2005) version of interactionist qualitative methodology. The article makes two related points: firstly, that insight can be gained by analyzing researcher-researched interactions as relations between intersectional social positions, and secondly, that antagonisms which occur in such interactions can be considered important data (Adler \& Adler, 2001; Andersen, 2005, 2006; Järvinen, 2004). While there has been some critique of the idea of problematic or 'bad' data (for instance Järvinen \& Mik-Meyer, 2005), the idea that experiences of antagonism can contain important information is still not part of mainstream qualitative method discussions.

\section{Methodological and theoretical points of departure}

Field relations are often discussed in literature on ethnography. This literature also describes how social categories such as gender, age and ethnicity can influence field relations (for instance Kristiansen \& Kroghstrup, 1999; Hammersley \& Atkinson, 1995). However, class is often omitted from the list of categories considered important to understand field relations. This is problematic, because research is often about groups which are situated at a lower class position than the researcher. In this article, I employ a multidimensional conception of class, which is mainly inspired by Bourdieu's sociology. Bourdieu's theoretization of class as a multidimensional continuum rather than a binary opposition, and the idea that class position is constituted by volume and composition of different forms of capitals, allow for grasping complex socio-cultural dimensions of class without excluding economic dimensions (Bourdieu, 1986).

Another problem with the usual treatment of social categories and field roles in literature about ethnography concerns the tendency of listing (adding) categories. Recent feminist theory has argued that social categories cannot be understood as separate entities which can simply be listed one after the other. On the contrary, social categories such as class, gender, ethnicity and 'race' are mutually constitutive in a non-additive way (Staunæs 2003). This theoretical point can be considered the common denominator of the literature about intersectionality (Crenshaw, 1989; 1991, Phoenix \& Brah, 2004; McCall, 2005; Gans, 2008; Choo \& Ferree, 2010). Following from this theoretical point, researcher-researched interactions may be understood as interactions between social positions which are themselves complex and intersectional.

How are such categories activated in interactions between researchers and researched, and how do they structure interactions between researcher and researched? Here we can draw on the classic phenomenological concept of typification (Schutz, 1967). This concept implies that when we engage people who we do not know personally, we assign people into types. We then expect them to behave, think and address us, as our experiences tell us people who belong to the same type usually do. This is the case in principle for both researcher and researched. As Järvinen \& Mik-Meyer point out in relation to qualitative interviews:

"Both the interviewer and the interviewee expect, that the activities, characteristics and opinions of the other part will conform to common conceptions of the category he or she belongs to - these expectations will permeate both the interaction in the interview and interview-material which is produced" (Järvinen \& Mik-Meyer, 2005: 32, my translation)

Combining intersectionality with the concept of typification implies that any meeting between researcher and researched is a meeting between complex intersectional configurations of social categories; and these configurations are the basis of typifications when they are interpreted through the prior experience of the actors involved. 
Importantly, the concept of typification also implies that the sorting of other people into types is done pre-reflexively and that that it is something we cannot wholly avoid. The concept thus points to mechanisms which are not dependent on intentions of the researcher or the researched, but which are rather dependent on the way the actors are positioned in social space and the prior experience of the actors involved.

The phenomenological conception of typification takes us some way in understanding how interactions between researcher and researched are socially structured. It is, however, necessary to include a perspective on institutional, historical and overall societal contexts, including how such contexts produce positions of power. Here it is possible to draw on Bourdieu, who suggests that we can think about relations as power relations between social positions rather than relations between personae. He argues that:

"...if a French person talks with an Algerian, or a black American to a WASP, it is not two persons who speak to each other but, through them, the colonial history in its entirety, or the whole history of the economic, political, and cultural subjugation of blacks (or women, workers, minorities etc.) in the United States" (Bourdieu \& Wacquant, 1992: 144)

If we apply this understanding of interactions as asymmetrical to the analysis of researcherresearched relations, it can be argued that these are also permeated by power and, furthermore, that this power is inscribed in the historical and social positions of the actors involved irrespective of their intentions and personal characteristics. Bourdieu thus argues that the power relations between the social categories of actors who engage in conversation structures the content of what can be said, how it can be said, the style of speaking etc. (2005: $176 \mathrm{ff}$.). Hence there is always power at play in researcher-researched interactions, qua the social positions involved ${ }^{2}$. Bourdieu then offers an understanding of the structural power which stems from positions in overall society and permeates the research interaction. He furthermore offers an understanding of relationality per se, rather than relations in the broad sense of the term. However, without conceptions suitable for grasping how agency is possible in asymmetrical conditions, a Bourdian perspective risks sliding into structuralist determinism. Here one can draw on the conception of counter power. Hence, Foucault argues that there is never power without counter power (Foucault 1983). However, a conception of counter power is perhaps not enough, as the blurriness and complexity of such relations is not merely a matter of turning the tables. This implies that power should be understood as unstable flows rather than as something social agents simply possess. One can also point to intersectionality itself as a source of complexity: Because power relations are relations between configurations which are themselves complex and intersectional, the actual interactions are impossible to predict. Informants may challenge the researcher by making otherwise muted or inactive categories relevant where the researcher is disadvantaged (See also kennedy-macfoy and Pristed Nielsen, this volume). It thus follows that both researcher and researched can be both dominant and dominated at the same time.

\footnotetext{
${ }^{2}$ Furthermore, the researcher has the power over the research - he or she decides which approaches to be taken, which questions to ask, how to interpret the data and how to represent the researched group in writing.
} 
Power and identity formation in research processes

Qualitative research entails processes of identity formation. Such processes are particularly clear in interviews. Identities are offered in interviews, as the researcher invites the interviewee to speak from specific subject positions (Järvinen, 2005). We may think of this as processes of interpellation/hailing (Althusser, 1971) or subjectivation(/subjectification ${ }^{3}$ ) (Foucault, 1988; Butler, 1990; Staunæs, 2003; Kofoed \& Staunæs, 2007). The concept of interpellation, central to Althusser's structural Marxist theory about identity, denotes that actors are called upon to take up subject positions through ideological processes. Similarly, subjectivation denotes how subjects are invited or recruited into being through discourse. As Youdell argues "research practice is wholly implicated in processes of ongoing subjectivation (of both the researcher and the researched)" (2006: 514). It follows from taking relationality seriously that it is not the researcher who is doing the hailing or subjectivation. Instead, I suggest that the hailing, or subjectivation, the invitation to occupy specific identities or subject positions, is the product of relationality; that is the consequence of the relation between the positions involved in the interaction. Consequently, the hailing and the forms of resistance sometimes produced cannot be reduced to a question of problematic or improper interview technique ${ }^{4}$. On the contrary, we can think of such processes as consequences of the identities which the relation offers the actors involved, given the way they are positioned socially both in and before the interview. An example might illustrate this point: In some of the interviews for my $\mathrm{PhD}$ project, the interviewees reacted in ways that indicated that they felt that they were being invited into a subaltern minority position. I argue that was the case because of the way both I and the interviewees were already socially positioned before entering the interview situation. This point is supported by the observation that parallel research projects have had similar experiences, notwithstanding differences in methodology, overall approach and location. The common denominator of these research projects was that the researcher was middleclass, adult, white ethnic majority, while the researched were young, working class, ethnic minority men (Andersen, 2005; Hviid, 2007; Staunæs 2007).

The observation that some of the young men ${ }^{5}$ reacted in ways that indicated they felt that they were being invited into a subaltern minority position implies that there are important discussions to be had here. The discussion of power above suggests that hailing and subjectivation must be brought into a dialogue with conceptions of complexity, counter power and agency, if one is to grasp the complexity of actual researcher-researched interactions. Judith Butler has problematized Althusser's understanding of interpellation for being overly deterministic by assuming that the hailing always succeeds in producing conforming subjects (1993, 1995). As mentioned earlier, a Foucauldian perspective points to the importance of counter power. This means that we need concepts which can grasp counter power in identity

\footnotetext{
${ }^{3}$ I use subjectivation and subjectification synonymously. The terms are used by different authors to describe the same processes.

${ }^{4}$ I am not a perfect interviewer or ethnographer, and I have made methodological mistakes in both research projects. There was, however, no proportionality between the size of these mistakes and the resistance I encountered from some informants. Likewise, resistance sometimes appeared before I had had the chance to make such mistakes. Hence, one overall argument in this article is that it is besides the point to reduce resistance to a reaction to such mistakes.

${ }^{5}$ In this text I, perhaps controversially, sometimes speak about the research participants in the plural (as 'the young men'). I do this not to suggest that they are an undifferentiated mass, but as shorthand for speaking about patterns in their reaction to me which they had in common.
} 
formation. I find Beverly Skeggs' use of the concept of disidentification useful. This concept, and the verb to disidentify (Skeggs, 1997), denotes an intentional, active and marked distancing from identity categories which have negative social value. It is therefore different from a mere absence of identification ${ }^{6}$. Also, when it comes to the question of identity formation in research interviews, we need to understand power as complex, blurred and unstable. A useful theoretical approach is therefore to interpret interview interactions as powerful, asymmetrical, yet open-ended, negotiations about identity. Hence Järvinen and Mik-Meyer (2005) argue that qualitative research interviews, as well as conversations during ethnographic fieldwork, can be understood as negotiations of social identity, as well as negotiations of what the social reality is taken to be.

\section{Context and methods}

The data stem from two research projects. My PhD project (see Jensen 2007, 2009, 2010, 2011) was mainly ethnographic. The research aimed at understanding masculinity among marginalized young ethnic minority men in Denmark. It also included a wider perspective on hybridity and subculture. The fieldwork took place in three youth clubs and a social project for excluded youths, in three Danish cities. Fieldwork was carried out from May 2001 to November 2005. A total of 126 observations were conducted. In addition to informal conversations, a total of 23 young men aged 13-25 were interviewed in 18 taped semi-structured qualitative interviews.

The youth clubs and the social project were chosen because of their locality and/or their social work with young people. Two were ordinary Danish youth clubs (first Aalborg Club, Århus Club), another a youth club assigned a special role in work with troubled ethnic minority youth (second Aalborg $\mathrm{Club}$ ) and the last a social project offering marginalized young people an alternative way to finish school (Copenhagen Youth Project). The young men had different ethnic minority backgrounds, with parents from Somalia, Turkey, Kurdistan, Palestine, Iran, Pakistan, Ex-Yugoslavia, Iraq, Ghana, Gambia and other national contexts.

Given the nature of fieldwork, the phrasing of the invitation to participate in the research varied, but all informants were informed that I was visiting the clubs to do research. The young men were typically informed that the research was about 'possible differences between boys and girls' (reflecting an interest in gender) and that I was interested in 'the culture that young people make themselves' (reflecting an interest in cultural agency). During the interviews, interviewees were asked questions about friends, music, family, relations to girls, school experiences, although the content varied as I attempted to address topics that interested the interviewees. Since the interviews took place in youth clubs and social projects, it is possible that some agreed to participate because of implicit pressure from social workers. Hence the PhD project can be problematized for obtaining what Kvale refers to as 'consent in institutions' (1997).

The other project is INTERLOC (see Christensen \& Jensen, 2011; Jensen \& Christensen, 2012). This project aimed at understanding the interplay between class, gender, ethnicity and 'race' in Aalborg East, a deprived residential section of Aalborg. Aalborg is a medium-sized Danish city with approximately 120,000 inhabitants situated in the Northern part of Denmark. Aalborg East, with 10,000 inhabitants, is the most multicultural area in Aalborg. The proportion of immigrants and descendants of immigrants is $18 \%$ (Skjøtt-Larsen, 2008), with considerable

\footnotetext{
${ }^{6}$ See also Goffman on the related concept of disidentifyers (1963, p. 60 ff.).
} 
variation between sub-areas. The area's minority population is made up of people with Somali, Palestinian, Turkish, Kurdish as well as a broad range of other ethnic backgrounds.

The INTERLOC-project employed several empirical methods, but here I use material from the 27 semi-structured qualitative interviews conducted during the project ${ }^{7}$.

The interviewees were sampled through a combination of personal contacts, random sampling and snowballing. Snowballing was carried out from different starting points. Contrary to the $\mathrm{PhD}$ project, the interviewees in the INTERLOC-project were under no pressure to participate in interviews. On the contrary, they volunteered in a way which may have caused a problem of self-selection: Fieldwork data indicate that a substantial proportion of ethnic Danes who live in the area are sceptical towards ethnic minority presence. However, these views are not much represented in the sample.

Interviewees were asked about a wide range of themes related to belonging to the neighbourhood, everyday life in the area, institutions and facilities, and relations between ethnic groups.

It should be emphasized that the mechanisms analysed here are not in a realist or positivist sense representative of the interactions between researcher and researched in either of the two projects. Indeed relations were often friendly and smooth. The data used in this article are, however, selected to pinpoint important methodological discussions about researching difference.

\section{What is the researcher expected to be interested in?}

In May 2009 we contacted potential interviewees for the INTERLOC-project. When I phoned Paul8, a 74 year-old ethnic Danish male retired skilled worker who I later learned had lived there since 1969, he immediately responded with a somewhat grumpy, "So, it is about how negative it is?!". This answer informed me about what Paul expected outsiders to be interested in about his area of residence. Although explicit questions like Paul's were rare, I consider them qualitatively important, not least because his answer was not the only answer of this kind: One potential informant simply explained to me that he had little to do with Aalborg East and then refused to participate, and others were reluctant until I carefully explained that the research was not meant to produce a negative image of the area, and added that I had lived there for several years myself.

This initial reluctance to participate indicates that some inhabitants of Aalborg East were well aware that the area is, in the terminology of Wacquant, subject to territorial stigmatization (Wacquant, 1996, 2007, 2008; Jensen \& Christensen, 2012). I further interpret these initial aassumptions about how the researcher might view the area as closely tied to the relation between the class positions of the actors involved in the interaction. After all, I was looking at a working class area from a cultural middle class position (see also Faber in this volume). They cannot, however, be reduced to mechanisms related to class. On the contrary, they point to the importance of locality. In contemporary segregated cities, locality itself comes to be a marker of privilege, power and status (or lack thereof). Locality as a form of socio-spatial differentiation

\footnotetext{
${ }^{7}$ For ethical reasons, I use only material from the interviews that I (and not the other researchers on the project) conducted for the INTERLOC project.

${ }^{8}$ All names in the article are pseudonyms.
} 
thus intersects with class and 'race' without being reducible to these. This is particularly true for Aalborg East, which for a long time has been subject to territorial stigmatization that is explicitly based on ethnicity (since the 80s the areas had been nicknamed Bangla Desh), and perhaps more implicitly based on fears and fantasies about the problematic (white) underclass (Jensen \& Christensen, 2012). Counter power is thus often articulated as an inclination to defend such stigmatized areas. In other words, the potential informants' expectations and reluctances were closely related to the non-additive intersection between my class position, ethnicity and the socio-geographical circumstance of me not living in Aalborg East. The example thus points to the relevance of geographical space to intersectional analysis (Valentine, 2007; Pini \& Leach, 2011). Accordingly, the reluctance could often be overcome when I explained that I had lived in the area for a number of years and knew it from within.

Compared to the informants of the INTERLOC-project, the young men whom I met during my $\mathrm{PhD}$ project were often far more explicit in their voicing of what they thought I was likely to be interested in. In one instance, I was explaining to a group of young men what my purpose for being in one of the clubs was. One of the young men then asked me with a slightly disapproving smirk 'So you're going out with us to observe when we beat down old ladies?' (The Århus club, Oct. 17th 2005). This example is illustrative of the way some of the young men reacted to the research. It thus implies what these young men expected that a type like me would be interested in about them. This typification can be understood by analyzing the relation between the categories present in the interaction. I was present as a white, ethnic Danish, middle class person. I consider this a position of privilege and (although not undisputed) power, as well as a position of socially legitimated masculinity. The young men were ethnic minorities and occupied lower class positions. Danishness, whiteness and middleclass status intersected and positioned me as a representative of normality, privilege and the majority in a way which cannot be understood as merely an addition of the categories at play. Similarly, the young men were constructed as others - pathological, criminal, representatives of an inferior minority culture - because of mechanisms tied to the relation between actors which were already classed, racialized and ethnified prior to the interview. The young men, however, actively negotiated and sometimes resisted this positioning, often through ironically or sarcastically commenting on popular conceptions, such as that young ethnic minority men are likely to 'beat down old ladies'. At the same time, comments like this can be interpreted as a way to address the relation between the masculinities involved; that is, a socially legitimated and allegedly peaceful white middle class masculinity and a perceived aggressive ethnic minority working class masculinity.

Overall this relationality led to different outcomes: Some of the young men emphasized during the interviews that they and/or their families were quite normal, thereby disidentifying from the social identity as different in a problematic way. One interviewee strongly denied being part of any group, as though to pre-empt an assumption on my part that he was a member of a socalled gang9. At other times, however, the young men did not reject being perceived as criminals. On the contrary, they made comments which, if taken at face value, would confirm the idea of the criminal hyper-masculine ethnic minority young man. An example is from one evening when I had just arrived at the Århus Club. I was alone with the young men for a brief moment while a social worker who was also in the club was busy in the office.

\footnotetext{
${ }_{9}^{9}$ See Alexander (2000) and Poynting et al (2001) for a critical analysis of the gang as a racialized concept.
} 
“... I am alone with the 3 boys who have shown up until now. They are fighting and acting quite noisy. One of them shouts 'We are just so criminal!' and pushes the other two."(Memo Århus Club, Oct. 14th 2005)

This was the first time I visited this particular club. I had been there for a few minutes and had not yet had time to introduce the PhD project. In other words, there is nothing I could have said which can explain that the young man announces that they are 'so criminal!'. I suggest that it is the categories present and the way they intersect which makes the young man assume that I the white, ethnic Danish middle class man - am probably there to obtain data about criminality. Furthermore, the club is known for carrying out crime-prevention programmes. It is, therefore, not unlikely that the young men have prior experiences with white, ethnic Danish middle class persons being interested in crime and crime-prevention.

In this exchange, the young man does not openly disidentify from the social identity as a criminal person. On the contrary, he exaggerates and dramatizes the popular perception of the hyper-masculine young immigrant criminal man. This, however, does not mean that identity is not negotiated. I argue that what is going on here is, in fact, a negotiation of this popular conception. Through caricature, the young man makes the point that he is well aware that powerful others might suspect him of being a criminal. In that respect, he is engaged in negotiating or resisting the identity as the criminal other which the relation is inviting him to occupy. At the same time, there is a power dimension to the setting. The reaction of the young men can be interpreted as an attempt to challenge and undermine the powerful position of the white middle class majority male by performing an aggressive ethnic minority masculinity. The challenge is based on a situational appropriation of popular representations, and amplified by the very concrete fact that I was alone in the room and a newcomer in the setting.

Another evening at the Århus Club, I was talking to some of the young men about cars. One of them was in the process of purchasing a Honda, and I asked him if he was getting a Civic ${ }^{10}$. When he confirmed that he was one of the other young men who was lying on the floor said 'immigrant car'11 (The Århus club, Oct. 17th 2005). One interpretation might be that he is simply noting that this is a car which is often preferred by young ethnic minority men. However, I would suggest that my presence as a white, ethnic Danish middle class male is central to understanding his remark. In that interpretation, he is making a comment, not on the car, but on the ethnic dimension of the situation, and he is demonstrating that he is aware that I am interested in them as ethnic minorities. In that sense, he is commenting on the presence of ethnic Danish whiteness just as much as he is commenting on his friend's choice of car. At the same time, there is a masculinity dimension to the interaction as the Honda Civic is a type of car associated with, and symbolic for, a specific type of masculinity, which is different from white, middle class masculinity.

Taken together these and numerous other episodes illustrate that the research was taking place in what Krumer-Nevo calls an 'arena of othering' (2002). Othering can be defined as discursive processes by which subordinate groups are defined into existence in a reductionist way which ascribe inferior characteristics to them (Spivak, 1985; Riggins, 1997; Jensen, 2011). Because of my positioning, which came to represent privilege, normality and majority, I became a representative of firstness while the young men came to represent otherness. This was the result

\footnotetext{
${ }^{10}$ Honda Civic is small, relatively cheap, and looks like a sports car when seen from the front.

${ }^{11}$ In Danish 'Udlændingebil'.
} 
of the mutually constitutive and reinforcing interplay between such categories as class, ethnicity and 'race'. However, the young men did not react passively to the way the relation subjected them to othering. They dis-identified from the subject position as the other, and actively resisted othering (see Jensen, 2009 for elaborations) and/or they played with hypermasculine imaginaries up against white middle class masculinity. In other words, the power present in the researcher-researched relation was not unchallenged (see kennedy-macfoy \& Pristed Nielsen, this issue). In the next section I will discuss further the complexities of the power relations in both projects.

\section{Power, counter power and reluctance}

As argued above, interactions between researcher and researched necessarily involve power. However, that does not mean that interactions unfold in a predictable way or that the researcher is always in power. One example from the INTERLOC-project is when I phoned Hanne, a 65 year old Danish retired office worker and active Social Democrat. I had already been in touch with Hanne at a local meeting where she volunteered to do an interview. When I asked her on the phone if we could make an arrangement she immediately replied "A dirty one?", and laughed. In this exchange, Hanne made sexual suggestions across age, class and gender categories in a way that momentarily unbalanced me. The way the categories of class, sexuality and gender intersect here, allowing for an older working class woman to unnerve a younger middle class man by pretending to make sexual suggestions, is itself an illustration of the complexity of intersectionality. In a sense, her response results in a destabilization of power relations: As a point of departure, I have the power to produce authoritative descriptions of the area where she lives - on the other hand, she has can make a sexual suggestion which cannot easily be responded to from the position of an 'appropriate', serious and gender reflexive young academic. The power asymmetry thus becomes blurred.

As noted above, the complexity of the intersections at play in researcher-researched interactions can open a space for such blurring of power, not least because the informants may sometimes be positioned higher than the researcher on some dimensions. One example is from my $\mathrm{PhD}$ project when I did ethnography at the Copenhagen Youth Project. One morning I was present in the school which was part of the project:

"The teacher says they have got a guest today [...] I stand up and start to explain that I am a writer and a researcher. They are obviously impressed when I tell that I am from a University. I speculate that the young people don't have a clear sense of what a University is, but they know it is something 'posh'. When I tell that I am from Aalborg, Abed remarks: 'Aalborg man, then you've gotten on the wrong train'." (Memo Copenhagen Youth Project, Dec. 17th 2002)

The excerpt is illustrative of how the complexity of the field relations leaves room for blurring social hierarchies. I am, as a starting point, positioned higher than the young men in terms of class (in terms of both economic capital and cultural capital, that is, being from a university), ethnicity and 'race'. However, when it comes to locality, they are situated at the centre, the Capital City of Denmark. I, on the contrary, work and live in a provincial town. Abed thus makes a socio-spatial distinction between centre and periphery relevant. It thus becomes possible for him to partially undermine my class position, and the outcome is a complex power relation where all actors present are both dominant and dominated, as well as both high and low status. 
At other times, the researcher-researched interactions took the form of clear-cut provocations. One example is from an evening at the first Aalborg Club.

"I am standing in a room with a group of boys. Ammar, who's got a lollypop in his mouth, starts to spit on the floor. Or he pretends to be spitting. Each time he looks at me, as if to check whether I react. It is obviously a provocation. When I don't react, his spitting becomes more and more obvious and exaggerated. At one point he clears his throat and spits. "Are you sick?" I ask him. "No, no" he mumbles. The moment after he spits, or pretends to spit, on my shoe. "Oops sorry" he says with a facial expression that signals challenge and provocation rather than an apology. For a brief moment I almost lose my temper. I give him a stern look and ask: "What are you doing?". Then he starts laughing: "Relax man, I was just joking. I'm not standing here spitting. Do you think I'm a total jerk?". I mumble something back. Shortly after, I move into the hallway where there is more light. There's no spit on my shoes or pants." (Memo First Aalborg Club, Sep. 20th 2003)

Ammar's way of challenging me can be analysed as an expression of counter power which is closely tied to the relation between the intersectional configuration of social categories present in the situation. I am white, ethnic Danish and middle class. Ammar has dark skin and curly hair, his parents migrated to Denmark from Somalia, and he is positioned lower in terms of class. In other words, a relation between the powerful and privileged, in contrast to the marginalized, structures the interactions in the field. I come to represent the white and classed authority, which results of my research published elsewhere (Jensen, 2010b, 2011) suggest that these young men experience being excluded from. At the same time, this is an interaction between masculinities: A legitimated white middle class masculinity often imagined as rational and peaceful, as opposed to a youthful working class minority masculinity rendered socially illegitimate and imagined as potentially aggressive. Analyzed in this light, it becomes understandable why Ammar challenges my position. His reaction may then be understood as a form of resistance or counter power. At the same time, the incident contains important substantial information about the relations between the social workers and the young people at this particular club, which were somewhat antagonistic.

The incident with Ammar was not the only example of antagonistic field relations during my $\mathrm{PhD}$ project. A few of the interviews were characterized by similar antagonisms. This was the case when I interviewed Tariq, a 13 year old boy with Pakistani parents. During the interview, which took place in the classroom of the Copenhagen Youth Project, Tariq was more than reluctant to participate. He commented on my questions, and called them ridiculous. At one point, I asked him whether he respected his parents. His reply was: 'Are you stupid or what?'. During the interview Tariq was drawing doodles on the school table making no attempt to hide what he was doing - itself a provocation. However towards the end of the interview, he took on the attitude of a zealous teacher, accusing me of having drawn the doodles:

Tariq: “What have you done there?"

SQJ: "What?"

Tariq: "Have you been given permission to draw?"

SQJ: “Do you want to stop?"

Tariq: "That is up to you"

SQJ: "Is there anything you would sort of like to say?"

Tariq: "I have nothing. Have you?" 
SQJ: “Nope, haven't got any more”

(Interview, Copenhagen Youth Project, Feb. 27th 2004)

The interview with Tariq contains several important analytical dimensions: It is clear that Tariq, as Ammar above, challenged my position as white authority. In addition, it is important that the interview took place in the classroom. In a sense, the setting of the interview, as well as the relation between the social categories, interpellated or subjectivated Tariq as a pupil. As a consequence, Tariq reacted to me as he would react to a teacher. This does not mean that Tariq thinks I actually am a teacher, but I may in terms of ethnicity, age and the fact that I belong to the cultural fraction of the middle class, look like and be positioned as a teacher, and this activates a repertoire of resistance practices related to schooling. This is important because many of the young men, including Tariq, had troublesome relations to school and some experienced school as othering and excluding (Jensen, 2007; see also Sewell, 1997; Alexander, 2000 for analyses of ethnic minority masculinities and schooling). In other words, power relations related to schooling are an important institutional context for understanding this interaction. However, Tariq does not only take on the role of the naughty or resistant pupil. On the contrary, he eventually claims the role of the teacher, the position of power and authority, and he then questions me about the drawing on the table. He then goes on to take the role of the interviewer, asking me if I have anything to say. In this excerpt, Tariq goes from challenging the position of the teacher to challenging the interviewer's privilege to ask questions. This leads to complex and ambiguous power relations. On the one hand, I may have the formal power over the interview situation (the right to ask questions etc.), but on the other hand, Tariq makes it literally impossible for me to get data in the form of rich accounts (although the interaction is in itself important data). Tariq challenges me, but does not succeed in anything else than making me annoyed. It is impossible to say that I hold power, but also impossible to say that the tables are simply turned.

The INTERLOC-project did not contain this type of explicit resistance. One reason may be that informants were not persuaded to participate in the same way as they sometimes were in my $\mathrm{PhD}$ project. The relation between the positions involved did, however, shape the interaction in more subtle ways. As noted above, there was some explicit scepticism at the initial contact. But after that, informants were careful rather than openly resistant or antagonistic. One example of a reluctant informant was Akram. Akram was in his 40s, unemployed and has a Middle Eastern ethnic background. The interview with him was an extreme but illustrative case. How the interview unfolded was captured in my notes:

"[I am briefing Akram about the interview] I end by asking if it is okay that I record the interview. Akram says that I can do that. But it does not take many minutes before he asks, if I can turn 'that thing' off 'so that I can relax'. The recorder is put in the bag and stays there for the rest of the interview. He asks whether I can't just take notes in writing, which I then do for the rest of the interview.

The interview is generally influenced by - perhaps even hampered by - Akram being very keen to protect his anonymity. Several times during the interview he says something then immediately asks me not to write it down [...] I also feel that he, as the interview progresses, is really cautious about what he says in the first place. And, as a third step of self-censorship, he afterwards asks me to go through the points I have written down. This time around he also asks me to omit information...." (Interview memo Oct.12th 2009) 
Once again this interaction can be analyzed as a relation between positions. A point of departure could be that this meeting takes place in a specific social and discursive context: contemporary public discourses in Denmark problematize Islam, ethnic minorities and socalled ghettoes (Røgilds, 1994; Wren, 2001; Hervik, 2004; Andreassen, 2005). When these discourses frame the interview, it is not irrational that Akram was careful about what he said during the interview. The position of the researcher works in relation to Akram's position in a specific discursive context. However, the relation cannot be reduced to the effect of ethnicity; ethnicity intersects with class and location (i.e. the fact that the researcher lived outside the area) to form a non-additive configuration of privilege and power. Akram is unemployed and lives in an area which outsiders often consider an immigrant ghetto. Another condition, which is linked to both class and ethnicity, is Akram's limited mastery of the Danish language. It is also a meeting between masculinities, one being white middle class and socially legitimated, the other subject to othering as Muslim men have been marked as inappropriate in Danish discourses (Andreassen, 2005). Taken together, these factors produce, in a non-additive and intersectional way, a strong power asymmetry. If Akram has typified the researcher as a powerful representative of the majority, and at the same time as one who can produce authoritative descriptions of the area, Akram's caution is understandable. At the same time, it is likely that Akram, like Paul above, is worried that his area of residence will be stigmatized further. Akram's and Paul's accounts in the interview are, therefore, inscribed in a larger negotiation of what the social reality about Aalborg East is taken to be.

Interviews with ethnic majority informants in the INTERLOC-project unfolded in a very different way than the interview with Akram. However, ethnicity also played an important role here. During some of the interviews, it was clear that some ethnic majority informants who experienced life in a multicultural area as problematic were somewhat careful in their wording. They seemed to be afraid of being labelled racist. One reason might be that the research was presented to them as being about life in a multicultural area. The informants may have interpreted this information as if the premise of the research - and the researcher - was promulticulturalism. Another, and somewhat overlapping, reason is that some informants appeared to assume that the researcher was left wing. This was clear in the way informants on the political right accounted for their political affiliation. One example is Henning, a 73 year old ethnic Danish pensioner. During the interview, Henning 'admits' several times to being on the political right. For instance he says that

“...when it comes to opinions I am right-wing, I have to admit that, I might as well say that. You can discuss different parties, whether you are for Venstre ${ }^{12}$ or Konservative ${ }^{13}$ and stuff like that, but that is the wing I support. I've got to admit that I do not like De Radikale ${ }^{14}$ very much. Even if they have skills, I do not have a lot of respect for them..." (Interview May 6th 2009)

Henning appeared to have a specific idea about the position he is talking to, at least in the sense that he assumes that it is likely that the researcher is not right wing. This perception of the interviewer shapes the way he speaks about his own political affiliation - without necessarily having consciously decided to do so. It is likely that the intersection of my class position (cultural fraction of the middle class), as well as my disciplinary affiliation as a sociologist, and

\footnotetext{
${ }_{12}$ Danish moderate right wing party with roots in economic liberalism.

${ }^{13}$ Danish moderate right wing party with roots in classical conservatism.

${ }^{14}$ Danish centre-left party with roots in political liberalism.
} 
my introduction of the INTERLOC-project led Henning to ascribe certain characteristics and intentions to me. This means that Henning adapts his answer to take into account which opinions I may likely have. The perhaps best illustration for this is the way he speaks about his antipathy of De Radikale. De Radikale is a centre-left party which is commonly perceived to appeal strongly to young academics from the fraction of the middle class with high volumes of cultural capital. Thus, taking my position into account, Henning may very well have assumed that I was sympathetic to De Radikale.

Another example of the reluctance to problematize multiculturalism is from an interview with Hanne (who was introduced above).

SQJ: "Now we have been talking a bit about gender and...what is your opinion regarding ethnic minorities, immigration, refugees and stuff like that?"

Hanne: "I feel like, I think that....honestly I felt at some point that it was becoming too much. And I may still think so. I think those who come here because they need it, they should be allowed to stay here. They should be treated fairly. But I think those who come here only to do crime should be sent out [...] It is not all of them I like, to tell you the truth..." (Interview Sep. 16th 2009)

This excerpt illustrates that Hanne is reluctant to address her skepticism towards the presence of ethnic minorities. It seems that she, like Henning, assumes that the researcher is left wing and pro-multiculturalism. As a further dimension she is, as mentioned above, an active Social Democrat. Her reluctance may therefore also in part be explained by her being at odds with the official party line.

The excerpts from the interviews with Henning and Hanne illustrate how informants assume that the researcher is left wing and pro-multiculturalism. Not necessarily because of something the researcher has said or done, but because of the relation between the positions. The reluctance and the admissions, however, clearly illustrate that there is a subtle form of power at play. Henning and Hanne are speaking to, and up against, a researcher who has the power to represent them as racists or nationalist. They relate to this power by attempting to find ways to speak of their opinions that cannot be normatively judged. From an identity perspective, Henning and Hanne are engaged in negotiating a viable identity: Henning is communicating that he is a legitimate and knowledgeable subject who is aware that being right wing is considered problematic in some parts of society. Hanne is communicating that she is a legitimate non-racist subject, despite her reservations towards some ethnic minorities.

\section{Conclusion}

In this article I have argued that researcher - researched interactions can be analyzed as relations between social positions which are themselves complex and intersectional. In my PhD project, ethnicity, class, age and masculinity seemed the most central categories for understanding these interactions, whereas in the INTERLOC-project, ethnicity and class were extremely important, but could only be analyzed by taking geographical location seriously as a significant dimension of the non-additive intersectional configuration.

It is obviously not possible to prove in any positivist or realist sense that such interactions are in fact relations between social positions. The aim here has been more modest, to suggest that insights can be gained from analyzing such interactions from this perspective. The illustrations have thus shown that mechanisms occur in the researcher-researched interactions which cannot 
be explained without taking the inter-relations between positions into analytical consideration. In other words, methodological dispositions cannot account for the mechanisms which appeared during the research. This point is supported by other research projects carried out by other researchers parallel to the $\mathrm{PhD}$ project having similar experiences.

One main argument has been that interactions which are experienced as antagonistic can be valuable data. This does not mean that they are particularly pleasant when they occur, or that one shouldn't strive to avoid them. However, if they occur, they may contain important information about the researched phenomena. To illustrate that such experiences are data, it is necessary here to include the wider findings of the projects.

In the INTERLOC-project, the interactions pointed towards ethnicity being extremely important for both minorities and majority, albeit, in quite different ways. The cautiousness of some minority informants towards the majority researcher implies that they felt excluded and othered in Danish society. This resonates with another finding from the project: Minority informants expressed a strong sense of belonging to the area, but felt excluded from Denmark as a nation (Christensen \& Jensen, 2011, 2012). On the other hand, a close reading of the way some majority informants accounted for their political opinions implies that they were skeptical towards the presence of ethnic minorities. Taken together, these observations resonate with a major finding of the project: Relations between ethnic groups in Aalborg East were peaceful, but at the same time very little actual interaction occurred (Christensen \& Jensen, 2012).

Another important observation from the researcher-researched interaction in the INTERLOCproject is that the interviewees across ethnicities often assumed that the researcher would have a negative view of the area. They sometimes indirectly expressed fear that the research would contribute to the negative labelling of the area where they live. This observation makes up a central part of the overall finding that the inhabitants of Aalborg East are painfully aware of living in a territorially stigmatized area (Jensen \& Christensen, 2012).

The researcher-researched interactions of the PhD project similarly contain data. The young men sometimes reacted to me as if I was the symbol of a white ethnic Danish society which they felt excluded from. At the same time, they sometimes had very specific ideas about which dimensions of their life I was likely be interested in. They did not, however, passively subjugate themselves to the authority of white middle class masculinity. On the contrary, they sometimes reacted with resistance or reluctance. On a concrete level, this is important data about their antagonistic relations to adult white male middleclass authority. On a more abstract level, this methodological experience was central to a main finding of the project: That the research participants experienced being othered, not only because of ethnicity, but as consequence of the intersection of their class, ethnicity and gender. The antagonistic character of some of the interactions, however, added an important dimension to this finding, as it indicated that the young men did not accept this othering, and that they sometimes resisted and disidentified from the position of the problematic other (Jensen, 2011).

\section{References}

Adler, P. A. \& Adler, P. (2001). The reluctant respondent. In J.F. Gubrium \& J.A. Holstein (Eds.) Handbook of interview research: Context and method, London: Sage Publications.

Alexander, C. E. (2000). The Asian Gang - Ethnicity, Identity, Masculinity. Oxford: Berg 
Althusser, L. (1971). Lenin and philosophy and other essays. London: New Left Books.

Andersen, K. V. (2005). Problembørn, pædagoger og perkere. PhD Dissertation, University of Copenhagen.

Andersen, K. V. (2006). Perker med no-life i Velfærds-danmark. Dansk Sociologi, 17(2): 27-41.

Andreassen, R. (2005). The Mass Media's Construction of Gender, Race, Sexuality and Nationality PhD Dissertation, University of Toronto.

Bourdieu, P. (2005[1972]). Udkast til en praksisteori. København: Hans Reitzels Forlag.

Bourdieu, P. (1986). The Forms of Capital. In J. G Richardson (Eds.) Handbook of Theory and Research for the Sociology of Education. Connecticut: Greenwood Press.

Bourdieu, P. \& Wacquant, L. J.D. (1992). An Invitation to Reflexive Sociology. Chicago: The University of Chicago Press.

Butler, J. (1995). Conscience Doth Make Subjects of Us All. Yale French Studies, no. 88: 6-26.

Butler, J. (1993). Bodies that matter. On the discursive limits of "sex". London: Routledge,

Butler, J. (1990). Gender Trouble. London: Routledge.

Choo, H. Y. \& Ferree, M. M. (2010). Practicing Intersectionality in Sociological Research: A Critical Analysis of Inclusions, Interactions, and Institutions in the Study of Inequalities. Sociological Theory, 28(2):129-149

Christensen, A. \& Jensen, S. Q. (2012). Stemmer fra en bydel. Aalborg: Alborg Universitetsforlag.

Christensen, A. \& Jensen, S. Q. (2011). Roots and Routes: Migration belonging and everyday life. Nordic Journal of Migration Research. 1(3): 1-10.

Crenshaw, K. W. (1991). Mapping the Margins - Intersectionality, Identity Politics and Violence Against Women of Colour. Stanford Law Review. 43(6): 1241-1299.

Crenshaw, K. W. (1989). Demarginalizing the Intersection of Race and Sex: A Black Feminist Critique of Antidiscrimination Doctrine, Feminist Theory and Antiracist Politics.' University of Chicago Legal Forum, University of Chicago 1989: 139-67.

Foucault, M. (1988). Madness and civilization. A history of insanity in the age of reason. New York: Vintage Books.

Foucault, M. (1983). The subject and Power. In: H.Dreyfuss \& P. Rabinow (Eds.), Michel Foucault: Beyond Structuralism and Hermeneutics, Chicago: University of Chicago Press.

Gans, J. C. (2008). Re-thinking intersectionality. Feminist Review, 89(1): 1-15. 
Goffman, E. (1963). Stigma -Notes on the Management of Spoiled Identity. Harmondsworth: Penguin Books.

Hammersley, M. \& Atkinson, P. (1995).Ethnography - Principles in practice 2nd edition. London: Routledge

Hervik, P. (2004). The Danish Cultural World of Unbridgeable Differences. Ethnos, 69(2): 247267

Hviid, K. (2007). No life. PhD Dissertation, Aalborg University.

Jensen, S. Q. (2011).Othering, Identity Formation and Agency. Qualitative Studies, 2 (2): 63-78.

Jensen, S. Q. (2010). Masculinity at the margins - othering, marginality and resistance among young marginalized ethnic minority men. NORMA, 5(1): 7-26.

Jensen, S. Q. (2009)."Er det noget med bander?" - om modstand, andenhed og positioner i et sociologisk feltarbejde. Dansk Sociologi, 20(1): 45-63.

Jensen, S. Q. (2007) Fremmed, farlig og fræk: Unge mænd og etnisk/racial andenhed - mellem modstand og stilisering. PhD. Dissertation, Aalborg University.

Jensen, S. Q. \& Christensen, A. (2012). Territorial Stigmatization and Local Belonging - A Study of the Danish Neighbourhood Aalborg East. CITY, 15 (1-2): 74-92.

Järvinen, M. (2005). Interview i en interaktionistisk begrebsramme. In M. Järvinen \& N. MikMeyer, Nanna (Eds.), Kvalitative metoder $i$ et interaktionistisk perspektiv. København: Hans Reitzels Forlag.

Järvinen, M. (2004) Hjemløse flygtninge og indvandrere. København: Hans Reitzels Forlag.

Järvinen, M. \& Mik-Meyer, N. (Eds.) (2005)Kvalitative metoder $i$ et interaktionistisk perspektiv. København: Hans Reitzels Forlag.

Kofoed, J. \& Staunæs, D. (Eds.) (2007): Magtballader: 14 fortællinger om magt, modstand og menneskers tilblivelse. København: Danmarks Pædagogiske Universitetsforlag.

Kristiansen, S. \& Krogstrup, H. K. (1999). Deltagende observation - introduktion til en forskningsmetodik. København: Hans Reitzels forlag.

Krumer-Nevo, M. (2002). The Arena of Othering: A Life-Story Study with Women Living in Poverty and Social Marginality. Qualititative Social Work, 1(3): 303-318.

Kvale, S. (1997). Interview. Hans Reitzels Forlag.

McCall, L. (2005). Managing the complexity of intersectionality. Signs, 30 (3): 1771-1800.

Phoenix, A. \& Brah, A. (2004). Ain't I a woman? Revisting Intersectionality. Journal of International Women's Studies, 5(3): 75-86. 
Pini, B. \& Leach, B. (2011).Transformations of Class and Gender in the Globalized Countryside. In B. Pini \& B. Leach, Belinda (Eds.) Reshaping Gender \& Class in Rural Spaces. Farnham: Ashgate.

Poynting, S., Noble, G \& Tabar. P (2001). Middle Eastern Appearances: "Ethnic Gangs", Moral Panic and Media Framing. Australian \& New Zealand Journal of Criminology, 34(1): 67-90.

Riggins, S. H. (1997). The Rhetoric of Othering. In S. H. Riggins (Ed.), The Language and Politics of Exclusion - Others in Discourse. Thousand Oaks: Sage

Røgilds, F. (1994). Avedøre - en forstad til Sarajevo?. In A. Madsen, S. Ejersbo \& S. Damkjær (Eds.)..Den kultursociologiske omtanke. København: Akademisk Forlag.

Schutz, A. (1967). The phenomenology of the social world. Evanston, IL: Northwestern University Press.

Sewell, T. (1997). Black Masculinities and Schooling: How Black Boys Survive Modern Schooling. Stoke on Trent: Trentham Books.

Skeggs, B. (1997). Formations of Class and Gender.London: Sage.

Skjøtt-Larsen, J. (2008) Aalborg Øst - En social og symbolsk profil. Sociologisk Arbejdspapir no. 24

Spivak G. C. (1985). The Rani of Sirmur: an essay in reading the archives. History and Theory, 24(3): 247-272.

Stanuæs, D. (2007) '"I am right behind him"- Managing Fear and Boys in the Time of the Danish Cartoon Crisis.'Paper at the Social- and Cultural Psychological Research Perspectives on the Intersection between Individualization - Identity - Ethnicity. University of Roskilde. October 2007

Staunæs, D. (2003).Where have all the subjects gone? Bringing together the concepts of intersectionality and subjectification. Nora, 11(2): 101-110.

Valentine, G. (2007). Theorizing and Researching Intersectionality: A Challenge for Feminist Geography. The Professional Geographer 59(1): 10-21.

Wacquant, L. J. D. (2008). Urban Outcasts - A Comparative Sociology of Advanced Marginality Cambridge: Polity

Wacquant, L. J. D. (2007).Territorial Stigmatization in the Age of Advanced Marginality' Thesis Eleven no 91: 66-77.

Wacquant, L.J. D. (1996). The Rise of Advanced Marginality: Notes on its Nature and Implications. Acta Sociologica, 39(2): 121-139.

Wren, K. (2001).Cultural racism: Something rotten in the state of Denmark?. Social \& Cultural Geography, 2(2): 141-163. 
Youdell, D. (2006). Subjectivation and performative politics - Butler thinking Althusser and Foucault: intelligibility, agency and the raced-nationed-religioned subject of education. British Journal of Sociology of Education, 27(4): 511-528.

\section{Author}

Sune Qvotrup Jensen is an Associate Professor in Cultural Analysis and Ethnography at the Department of Sociology and Social Work at Aalborg University, Denmark. Email: qvotrup@socsci.aau.dk

Acknowledgement: I thank Stine Thidemann Faber, Morten Kyed and Lene Myong who provided comments and literature suggestions for this paper. I also thank Ann-Dorte Christensen with whom I conducted the research in the INTERLOC-project. The INTERLOCproject received funding from the Danish Social Science Research Council (FSE). 